\section{Las nuevas funciones del Estado}

Arturo Fernández

Arturo Fernández es Investigador del CONICET,

Profesor de las Universidades de Rosario

y de Buenos Aires, Director de la Maestría en Investigación

Social de la UBA y Presidente de la Sociedad Argentina

de Análisis Político (SAAP).

Dirección: Facultad de Ciencias Sociales, UBA,

Marcelo T. de Alvear 2230, (1122) Buenos Aires.

Tel. (5411) 45083800.

E-mail: fernan@piette.edu.ar

\section{Resumen}

El artículo trata de la ampliación de las funciones esenciales del Estado (ocurrida entre 1930 y 1970) y los cambios introducidos por la globalización financiera, económica y comunicacional, la cual tiene efectos en el proceso socio político. Estos cambios se suceden a partir de 1980. Se puede constatar que en áreas periféricas como la latinoamericana, la transformación y reducción de las funciones del Estado puede afectar su naturaleza y su propia posibilidad de supervivencia. Sin embargo se entiende por "nuevas funciones del Estado" su creciente interdependencia y relacionamiento con otras entidades estatales, la formación de organizaciones regionales y las diversas formas de descentralización. La idea del rol central del Estado va dando lugar a nuevos significados sobre lo político y el proceso político. Entonces, las «nuevas funciones del Estado», reforzadas por una activa participación de la sociedad, pueden facilitar en cualquier región del mundo, procesos de democratización, rendición de cuentas de los políticos y administradores públicos, reforzamiento de la ciudadanía, y control eficiente del poder por diversos actores sociales.

\section{Summary}

The article analyses the tension between the enlargement of the functions of the State (1930-1970) and the changes that have been introduced by the financial, economical and communicational globalization. It is clear that in peripherals regions of the world as in Latin America these changes, the transformation and the reduction of the State can affect its nature and its own possibility of survival. However we understand as unew functions of the State" the processes of increasingly interdependence and relationships with other states, the creation of regional organizations and several types of decentralization.

The idea about the central role of the State have been replaced by new meanings about politics and political process. These "new functions of the State» with the participation of the society can improve democratization, accountability of politicians and public officers, empowerment of citizenship, and efficient control of the power by civil and social actors in any region of the world. 